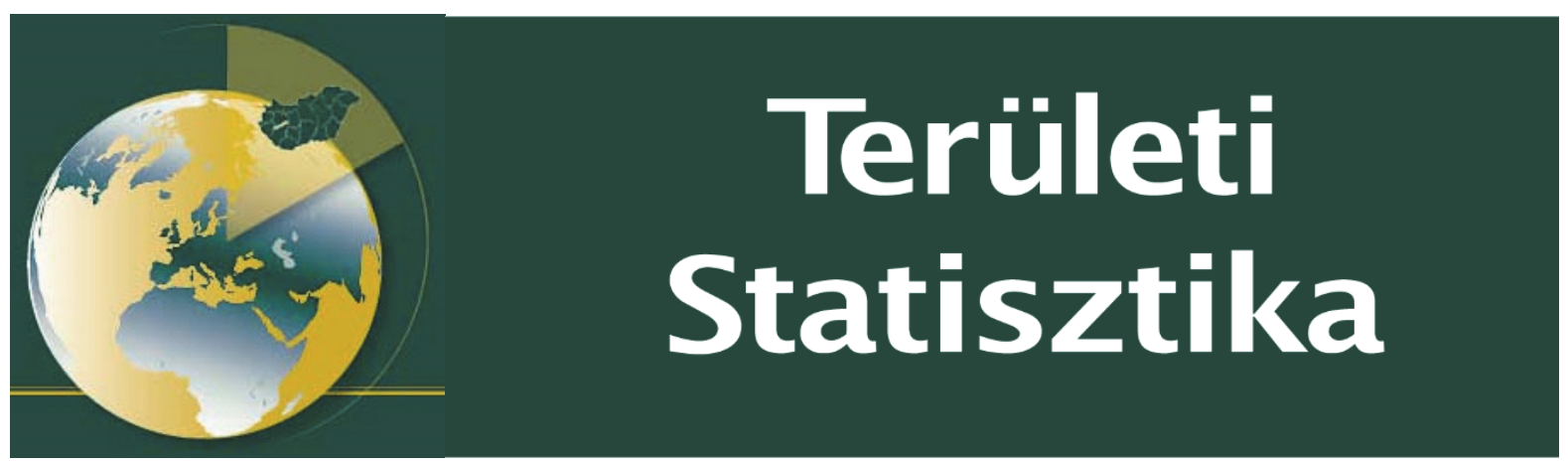

Közzététel: 2019. szeptember 30.

A tanulmány címe: Szerző:

A boldogság mint az okos városok mérésének új, lehetséges módszere

Barsi Boglárka, MTA KRTK RKI, Győr E-mail: barsib@rkk.hu https://doi.org/10.15196/TS590505

Az alábbi feltételek érvényesek minden, a Központi Statisztikai Hivatal (a továbbiakban: KSH) Területi Statisztika c. folyóiratában (a továbbiakban: Folyóirat) megjelenö tanulmányra. Felhasználó a tanulmány, vagy annak részei felhasználásával egyidejüleg tudomásul veszi a jelen dokumentumban foglalt felhasználási feltételeket, és azokat magára nézve kötelezönek fogadja el. Tudomásul veszi, hogy a jelen feltételek megszegéséból eredö valamennyi kárért felelösséggel tartozik.

1) A jogszabályi tartalom kivételével a tanulmányok a szerzői jogról szóló 1999. évi LXXVI. törvény (Szjt.) szerint szerzői műnek minősülnek. A szerzői jog jogosultja a KSH.

2) A KSH földrajzi és időbeli korlátozás nélküli, nem kizárólagos, nem átadható, térítésmentes felhasználási jogot biztosít a Felhasználó részére a tanulmány vonatkozásában.

3) A felhasználási jog keretében a Felhasználó jogosult a tanulmány:

a) oktatási és kutatási célú felhasználására (nyilvánosságra hozatalára és továbbítására a

4. pontban foglalt kivétellel) a Folyóirat és a szerző(k) feltüntetésével;

b) tartalmáról összefoglaló készítésére az írott és az elektronikus médiában a Folyóirat

és a szerző(k) feltüntetésével;

c) részletének idézésére - az átvevő mű jellege és célja által indokolt terjedelemben és az eredetihez híven - a forrás, valamint az ott megjelölt szerző $(\mathrm{k})$ megnevezésével.

4) A Felhasználó nem jogosult a tanulmány továbbértékesítésére, haszonszerzési célú felhasználására. Ez a korlátozás nem érinti a tanulmány felhasználásával előállított, de az Szjt. szerint önálló szerzői műnek minôsülő mű ilyen célú felhasználását.

5) A tanulmány átdolgozása, újra publikálása tilos.

6) A 3. a)-c.) pontban foglaltak alapján a Folyóiratot és a szerző(ke)t az alábbiak szerint kell feltüntetni:

„Forrás: Területi Statisztika c. folyóirat 59. évfolyam 5. sqámában megjelent, Barsi Boglárka által irt, A boldogság mint az. okos városok mérésének üj, lehetséges módszere c. tanulmány"

7) A Folyóiratban megjelenő tanulmányok kutatói véleményeket tükröznek, amelyek nem esnek szükségképpen egybe a KSH, vagy a szerzők által képviselt intézmények hivatalos álláspontjával. 


\section{A boldogság mint az okos városok mérésének úi, lehetséges módszere *}

\section{Happiness as a possible new method for evaluating smart cities}

Barsi, Boglárka A tanulmány az okos városok fogalmának új as-

ELKH Közgazdaság- és Regionális Tudományi Kutatóközpont Regionális

Kutatások Intézete,

Győr

E-mail: barsib@rkk.hu pektusát mutatja be, mely a technológiaközpontúság irányából az emberközpontúság felé mozdul el. Ebben az értelmezésben az okos városnak nem egy szegmense, hanem a végső célja az életminőség és a boldogság növelése. A boldogság, a szubjektív jóllét és az életminőség fontos, gyakran kutatott témává vált a társadalomtudományok területén, de mind ez ideig a regionális tudományokban kevesebb figyelmet kapott. A szerző felvázolja a boldogság területi aspektusait, végül ismerteti, hogy a boldogság, a jóllét

Kulcsszavak: beemelése az okos városokkal kapcsolatos vizsokos város, boldogság, jóllét, értékelés gálatokba milyen módon segíti elő e városok végsô céljának, azaz a polgárok számára jobb életminőséget kínáló települések mind teljesebb körű értelmezését és nyomon követését.

* Az „Okos városok és területi statisztika” címmel rendezett konferencián, 2019. február 27-én tartott előadás szerkesztett változata.

Területi Statisztika, 2019, 59(5): 555-574; DOI: 10.15196/TS590505 
We aim to present in our study a new aspect of the smart city concept which moves from a technology-centred approach toward a people-centred one. In this interpretation improvement of quality of life and happiness is not a segment, but the ultimate goal of smart cities. Happiness, wellbeing and quality of life have become an important topic in social sciences, but received less attention in regional studies. The author presents the spatial aspects of happiness and in the end the paper outlines how incorporation of

Keywords: happiness and well-being into the smart city smart city, surveys helps to promote a better understanding happiness, and examination of the more comprehensive and well-being, ultimate goal of cities: being inclusive, better evaluation quality of life offering settlements.

Beküldve: 2019. május 14.

Elfogadva: 2019. július 9.

\section{Bevezetés}

A város lakóinak jólléte, boldogsága már az ókorban is központi szerepet játszott a városról való gondolkodásban. A város nem pusztán egy fizikai mechanizmus vagy mesterséges konstrukció. A várost ugyanis emberek hozzák létre és múködtetik, így az emberi természet terméke (Park et al. 1925). Már Arisztotelész etikájában (Arisztotelész 1997) is a boldogság (görögül eudaimonia) állt a középpontban, és arra kereste a választ, hogy az ember a társadalmon belül hogyan érheti el a legnagyobb boldogságot. A modern politikai gondolkodásban a boldogságnak továbbra is központi szerepe van, amit az elsősorban John Stuart Millhez köthető utilitarionizmus (haszonelvűség) helyezett a legfontosabb célok közé (Ludassy 1991). E szerint mind egyéni, mind közösségi szempontból az emberek legfontosabb célja a boldogság maximalizálása és a fájdalom, szenvedés minimalizálása. Csíkszentmihályi szerint (1992) az ember minden más célt abból a szempontból értékel, hogy az mennyiben járul hozzá a boldogságához.

A városfejlesztésben széleskörűen elterjedt okos városnak nincs egységes, elfogadott definíciója. ${ }^{1}$ Tartalmát jelentős mértékben meghatározzák a szövegösszefüggések, az alkalmazás körülményei, továbbá a fogalmat használó személyek érdekhordozó háttere. Egy bizonyos, a koncepció szorosan kapcsolódik az információs és

${ }^{1}$ Az okosváros-fogalmakról és -definíciókról lásd Mora et al. (2017).

Területi Statisztika, 2019, 59(5): 555-574; DOI: 10.15196/TS590505 
kommunikációs technológiák (IKT) alkalmazásához, a digitalizáció elterjedéséhez és az internethez. Ebben az értelemben számtalan fogalmi előzménye van, sok esetben párhuzamosan vagy akár szinonimaként is használták olyan más koncepciókkal, mint a digitális város, az intelligens város, melyeket már az 1990-es években is gyakran alkalmaztak, és léteznek olyan „társkoncepciók” is, mint az információs város, az innovatív város, a virtuális város, az ökováros, a zöld város, a fenntartható város. Harrison és Donnelly (2011) szerint az okos város fogalma az 1990-es évek végén kezdett elterjedni, az okos növekedéssel kapcsolatos tanulmányok révén.

Az akadémiai eredetú definíciók sorában jelentős befolyású meghatározás Giffinger és szerzőtársaitól (2007) származik. E szerint az okos város olyan város, mely előremutatóan és kiválóan teljesít 6 fő területen (gazdaság, mobilitás, kormányzás, környezet, emberek, élet), továbbá épít a független, tudatos, önálló döntésekre képes polgárainak képességeire és tevékenységeire, cselekedeteire.

Az okos városok átfogó, teljes körű meghatározását - véleményünk szerint Caragliu és szerzőtársai $(2011,50$. old.) adták: „mikor az emberi és társadalmi tőkébe, valamint a hagyományos (például közlekedés) és modern (IKT) kommunikációs infrastruktúrába történó befektetés fenntartható gazdasági növekedést és magas életminőséget generál, miközben az erőforrásokat bölcsen kezelik, és a kormányzás a város lakóinak részvételén alapul."

Az okos város tehát folyamatosan fejleszti, javítja a társadalmi, a gazdasági és a környezeti fenntarthatóságot, válaszol a klímaváltozás, a politikai és a gazdasági instabilitás kihívásaira, javítja a társadalommal való kapcsolatát, együttmúködésen és részvételen alapuló vezetési módszereket alkalmaz, az IKT-t és az általa gyújtött, feldolgozott adatokat úgy használja, hogy magasabb színvonalú szolgáltatásokat és életszínvonalat biztosítson a városban élők számára, miközben figyelembe veszi a jelen és a jövő generáció igényeit, valamint nem rombolja a természeti környezetet.

A boldogság - hasonlóan az okossághoz - nehezen megragadható fogalom, ezért sokáig nem képezte tudományos értékű, empirikus kutatások tárgyát, annak ellenére, hogy a boldogság mint politikai cél korán bekerült a közgondolkozásba. A szakirodalomban a boldogság helyett gyakran használják a szubjektív jóllét (Diener 2006, Hills-Argyle 1998, Eid-Larsen 2008), vagy az életminőség fogalmát is (Diener 2000, Ratzlaff et al. 2000, Shin-Johnson 1978, WHO 1998). Ez arra enged következtetni, hogy a boldogság meghatározása - az okosság fogalmához hasonlóan - függ a szövegösszefüggésektôl és a fogalmat használó személyek hátterétôl.

A boldogság kutatásával eleinte szinte kizárólag a filozófia, majd utána a pszichológia, a szociológia, továbbá a politikatudomány foglalkozott (Diener et al. 1999, Lane 2000), és a közgazdaságtanban a XX. század végén jelent meg, elsősorban Easterlin (1974) nyomán. A jóllét, a boldogság közgazdasági meghatározó elemeit vizsgáló empirikus szakirodalom jórészt különböző térbeli megfigyeléseken alapszik, ennek ellenére a boldogság területi dimenzióinak meghatározásával a vizsgálatok

Területi Statisztika, 2019, 59(5): 555-574; DOI: 10.15196/TS590505 
napjainkig - néhány kivételtôl eltekintve - kevéssé foglalkoztak (Clark et al. 2008, Aslam-Corrado 2007, Brereton et al. 2008, Ballas 2007).

Giffinger és Gudrun (2010) a neoklasszikus városfejlődési és növekedési elméletre alapozva alakították ki értékelési rendszerüket, mellyel az okos városokat vizsgálták, és az életminőség mint tényező része volt elemzésüknek. Ugyanakkor más kutatók (Ballas 2013, Dameri 2017, Neirotti et al. 2014) úgy érveltek, hogy az életminőség, a boldogság nem egy elkülönült dimenzióját jelenti az okos városoknak, hanem a végső céljukat, tehát a város múködtetésének minden lépését, a város életébe való minden beavatkozást a város lakóinak boldogsága, életminőségének javítása határozza meg. Jelen tanulmányunkban - ez utóbbi elméletet osztva - mutatjuk be, hogyan használhatjuk a boldogságot egy város okosságának mérésére.

\section{A boldogság, a jóllét területi dimenziói}

Layard (2005) munkájában összefoglalta az egyének boldogságát meghatározó tényezőket. A felnőtt népesség boldogságát 7 fő tényezőben határozza meg: pénzügyi helyzet, családi kapcsolatok, munka, közösség és barátok, egészség, személyes szabadság, személyes értékek.

Ugyanakkor a település is, ahol élünk, meghatározó hatással van a boldogságunkra. Ebben az a tényező játszik kulcsszerepet, hogy a helyek elősegítik az emberi, a társadalmi kapcsolatok, kötődések kialakulását, nemcsak az emberekhez, hanem a közösségekhez, a helyhez is. Ezek pedig a boldogság és az életminőség nagyon fontos tényezői. A város boldogsága úgy definiálható, mint egy olyan koncepció, mely pozitív érzékelést tulajdonít a helynek, ahol az emberek élnek, arra ösztönözve óket, hogy hosszú időt töltsenek a településen és/vagy az eddigi tapasztalataik alapján újra úgy döntsenek, hogy ott kívánnak élni (Sepe 2017). Ahogy a társadalom változik, úgy változhat a tér érzékelése is. Az épített környezethez kapcsolódó érzések, értelmezések módosulnak a változó társadalmi érzékek, a társadalmi-gazdasági szerveződési minták és az életstílus következtében (Porteous 1977).

Cohen (2012) kidolgozta az ún. okosváros-kereket, mely azt mutatta be, hogy a technológia és az innováció miként teszi a városokat okosabbá. Az okosvároskerékben a következő 6 pillért szerepeltette:

- Okos gazdaság (vállalkozás és innováció, termelékenység, lokális és globális összekapcsoltság, összekötöttség).

- Okos környezet (zöld épületek, zöld energia, zöld várostervezés).

- Okos kormányzat (elérhető kereslet és kínálat szerinti politika, átláthatóság, a nyilvános adatok, az IKT-szolgáltatások és az e-kormányzás elérhetôvé tétele).

- Okos életkörülmények (egészség, biztonság, élénk kulturális élet és boldogság). 
- Okos közlekedés (integrált IKT-szolgáltatások, a tiszta, nem motorizált közlekedési formák előtérbe helyezése, vegyes típusú használat).

- Okos emberek (kreativitás, befogadó társadalom, XXI. századi oktatás).

Cohen (2015) tanulmányában úgy vélte, hogy az okosváros-projekteknek, -kezdeményezéseknek 3 fejlődési szakasza van. Az első szakasz az ún. Okos városok 1.0, technológiavezérelt, elsősorban a nagy multinacionális vállalatok piacszerzési törekvéseihez kapcsolódott. A vállalatok új technológiákat, alkalmazásokat kínáltak, a városok megvették és használták azokat, anélkül, hogy átfogó stratégiájuk lett volna okos város kialakítására, vagy háttér-információval rendelkeztek volna arról, miképpen hatnak ezek a technológiák a városlakók életminőségére.

A második, az Okos városok 2.0., a városok vezérelte szakasz, melynek során egy haladó gondolkodású városvezető, városvezetés veszi át a kezdeményezést, meghatározva azt, hogy az okos technológiáknak és innovációknak milyen szerepük lehet a város jövőjében. Előtérbe kerül annak a figyelembevétele is, hogy a technológiák milyen módon hatnak a városlakók életminőségére.

Végül a harmadik szakaszban, az Okos városok 3.0 során, a városvezetôk a városlakókkal közösen alakítják, formálják a városokat, a ő igényeikre koncentrálva. E szakasz megjelenése indította el Cohent (2017) is azon az úton, hogy - egy teljesen más szemléletet követve - már a boldogságot mint végső célt helyezze a városok vizsgálatának középpontjába, és megalkossa a boldog város hexagonját, melynek elemei a következők:

- Biztonság és egészség.

- Bejárhatóság és elérhetőség (a szolgáltatások könnyú elérhetősége, a gyalogos és a kerékpáros közlekedés prioritása, közösségi közlekedés).

- Tiszta és zöld (zöld területek, tiszta levegó, szabadtéri rekreációs övezetek).

- Közös jóllét (megfelelő oktatás, hozzáférés a megfelelő lakhatáshoz, ételhez, sokszínúség).

- Társadalmi kapcsolatok (barátok, segítő közösség, könnyen elérhető lehetôségek más emberekkel való találkozásra).

- Kulturális és civil büszkeség (kultúra, demokrácia stb.).

Az említett két eszközben sok az átfedés és a hasonlóság. Az okosváros-kerék a városmenedzsment egyfajta eszközeként múködik, a város irányítói, múködtetôi számára útmutatást ad arról, miként lehet egy város okosabb. A boldog város hexagonja viszont a város polgárait helyezi a középpontba, és azt mutatja meg, hogy mi teheti egy város lakóit boldogabbá. Cohen (2017) szerint az okos városokat úgy kell kialakítani, hogy minden intézkedés, projekt az emberek boldogságát szolgálja. A boldog város hexagonja tehát jól tükrözi az okos városokról való gondolkodás megváltozását.

A területi dimenziót alapvetően kétféle módon lehet beemelni a boldogságkutatásokba. Egyrészt vizsgálható, mi határozza meg azt, hogy milyen arányban élnek boldog vagy boldogtalan emberek ugyanazon a helyen, másrészt kimutathatók

Területi Statisztika, 2019, 59(5): 555-574; DOI: 10.15196/TS590505 
az adott helyen élő emberek boldogságát vagy boldogtalanságát befolyásoló tényezők (Ballas-Tranmer 2012).

A boldogság vizsgálatába földrajzi tényezőket is beemelő kutatások alapvetően 3 témakör köré csoportosíthatóak. Egyik csoportba azok a kutatások tartoznak, melyek a vidéki és a városi térségek boldogságát hasonlítják össze (Cummins et al. 2003, Davern-Chen. 2010, Knight-Gunatilaka 2010, Millward-Spinney 2013, Shucksmith et al. 2009). A második csoportban pedig azok a kutatások találhatók, melyek azt vizsgálják, hogy milyen hatással vannak a "szomszédok” társadalmigazdasági jellemzői az adott területen élők boldogságára (Luttmer 2005, Clark 2003). Végül a harmadik csoportba sorolhatók azok, a már egészen korán megjelent kutatások, elemzések, melyek azt állították, hogy a település szerkezetének, fizikai felépítésének meghatározó hatása van az ott élők boldogságára.

Jacobs (1961) városgondolkodó úgy érvelt, hogy a város fizikai megjelenésének, dizájnjának nagy szerepe van abban, hogy mennyire vonzó a város. Meghatározza továbbá azt is, hogy a város biztonságos-e, élettel teli-e, érdekes-e. Azt állítja, hogy a vegyes használatú városi területek és az aktív gyalogos élet nagymértékben befolyásolják egy város vonzóságát, és kiemelkedően pozitív hatással vannak a városlakók személyes jóllétére. Lehetôvé teszik ugyanis a személyes kapcsolatok, a közösség, a felelősség és a bizalom kialakulását. Elméletében vegyes használatú helyeknek nevezi azokat a városi tereket, ahol nem különülnek el egymástól a lakó-, a kereskedelmi-üzleti, a kulturális, az intézményi és a szórakoztatási funkciók, hanem azok fizikailag és funkcionálisan is integráltan múködnek.

Oldenburg (1989) szintén megerősíti az ún. harmadik helyek fontosságát. Az első hely az otthonunk, a második hely a munkahelyünk, a harmadik hely pedig egy ezektől független közösségi tér, ahol rendszeresen összejöhetnek a hasonlóan gondolkodó, egymásra kíváncsi emberek. Ezek a terek (közparkok, kávéházak, parkok, közösségi központok, éttermek, kisboltok, fodrászatok stb.) társadalmi kapcsolatok kialakítását és ápolását teszik lehetővé, és jelentősen hozzájárulnak a személyes boldogsághoz. Az autóközpontú helyek, továbbá azok, ahol a munka és a rekreáció, a bevásárlás elválik egymástól, negatívan hatnak a boldogságra. Putnam (2000) igazolta, hogy az ingázás ideje és a közösség életében való részvétel egymással összefüggésben áll, minden plusz 10 perc napi ingázási idő 10\%-kal csökkenti a közösség életében való részvételt. Úgy véli, hogy az ingázással töltött idô minden másnál jobban magyarázza a társadalmi tôke nagyságát. Leyden (2003) ún. bejárhatósági indexet használva bizonyította, hogy azok az emberek, akik egy gyalogosan bejárható, vegyes használatú területen éltek, sokkal jobban ismerték a szomszédaikat, nagyobb volt irántuk a bizalmuk, társadalmilag és politikailag is aktívabbak voltak, mint azok, akik egy autóközpontú, kizárólag lakóövezetként használt városrészben éltek, minden más tényező változatlansága mellett.

Montgomery (2013) szintén úgy véli, hogy a városok felépítése, dizájnja jelentős hatással van az ott élők boldogságára. A városokat úgy kell felépíteni, alakítani, hogy azok lehetővé tegyék a családtagok, barátok és akár idegenek közötti kapcsolatok

Területi Statisztika, 2019, 59(5): 555-574; DOI: 10.15196/TS590505 
erősítését, mivel ezek a kapcsolatok adnak értelmet az emberi életnek, és alakítanak ki kötődést a városhoz.

Leyden és szerzőtársai (2011) 10 kiválasztott nagyváros boldogságának vizsgálatával igazolták, hogy a városlakók önbevalláson alapuló boldogsága szoros összefüggést mutat az épített környezettel, továbbá azzal, hogy milyen módon tartják karban az említett helyeket.

A boldog települések kihasználják az okos világ adta lehetőségeket, és a technológiát olyan módon alkalmazzák, hogy a város múködése nemcsak hatékonyabb legyen, hanem a városlakók elégedettsége, életminősége, érzelmi és lelkiállapota is jobb legyen, a városi szolgáltatások minősége, elérhetősége, egyszerűsége, hasznossága növekedjen. Ez a kiindulópontja annak a mérési módszernek, mely a boldogságot, az életminőséget és az elégedettséget mint az okos városok legfontosabb jellemzőit méri, értékeli. A társadalmi környezet, tehát a megbízhatóság, az igazságosság és az autonómia szintén mind elősegítik egy település boldogságát (Bin Bishr 2018). Az IKT e területek sikeres múködéséhez, tehát a városok boldogságához is jelentósen hozzájárulhat. Ha egy város életében a technológiák nem jelentenek hozzáadott értéket, azaz öncélúak és nem támogatják az életminőség növekedését, akkor azt nem is tekinthetjük okos városnak.

\section{A boldogság mint új mérési eszköz}

Számtalan értékelési módszer, modell született az okos városok múködésének feltárására, melyek célja az okosváros-koncepció megértése, céljainak, felépítésének, kiterjedésének magyarázata. Az okosság fogalmának sokrétűsége összekapcsolódik a városok komplexitásával, mely szükségessé teszi, de egyben meg is nehezíti megfelelő értékelési módszerek kidolgozását (Barsi 2018).

Ugyanakkor Magyarországon több tanulmány, kutatás is foglalkozott a városi térségek tipizálásával, valamint a városok és az innovációk, új technológiák kapcsolatának elemzésével (Tóth 1996, Beluszky 1999, Beluszky-Gyóri 2006, Csapó 2002, Kőszegfalvi-Tóth 1998, Dövényi 2003, Rechnitzer et al. 2003, Lengyel-Rechnitzer 2000, Rechnitzer 2002, Barsi-Csizmadia 2001, Barsi 2002, Lados-Horváthé Barsi 2011).

Az indikátorok és indexek használatának számtalan előnye van egy város okosságának értékelésében. A városrangsorok mindig a figyelem középpontjába kerülnek, mind a közéletben, mind a tudományos életben. Vitát váltanak ki arról, hogy mit is jelent az okosság, a versenyképesség, az életminőség, és így segítenek abban, hogy újra gondoljuk a korábban megfogalmazott stratégiákat vagy fejlesztési prioritásokat. E rangsorok lehetővé teszik a városok pozicionálását, városmarketing-eszközként szolgálhatnak, és hozzájárulhatnak a város vezetőinek sikerességéhez (Giffinger-Gudrun 2010). Az indikátorok használata viszonylag egyszerű, világos, könnyen magyarázható, vizualizálható és érthető. Nem véletlenül terjedtek el és váltak közkedveltté (1. táblázat).

Területi Statisztika, 2019, 59(5): 555-574; DOI: 10.15196/TS590505 


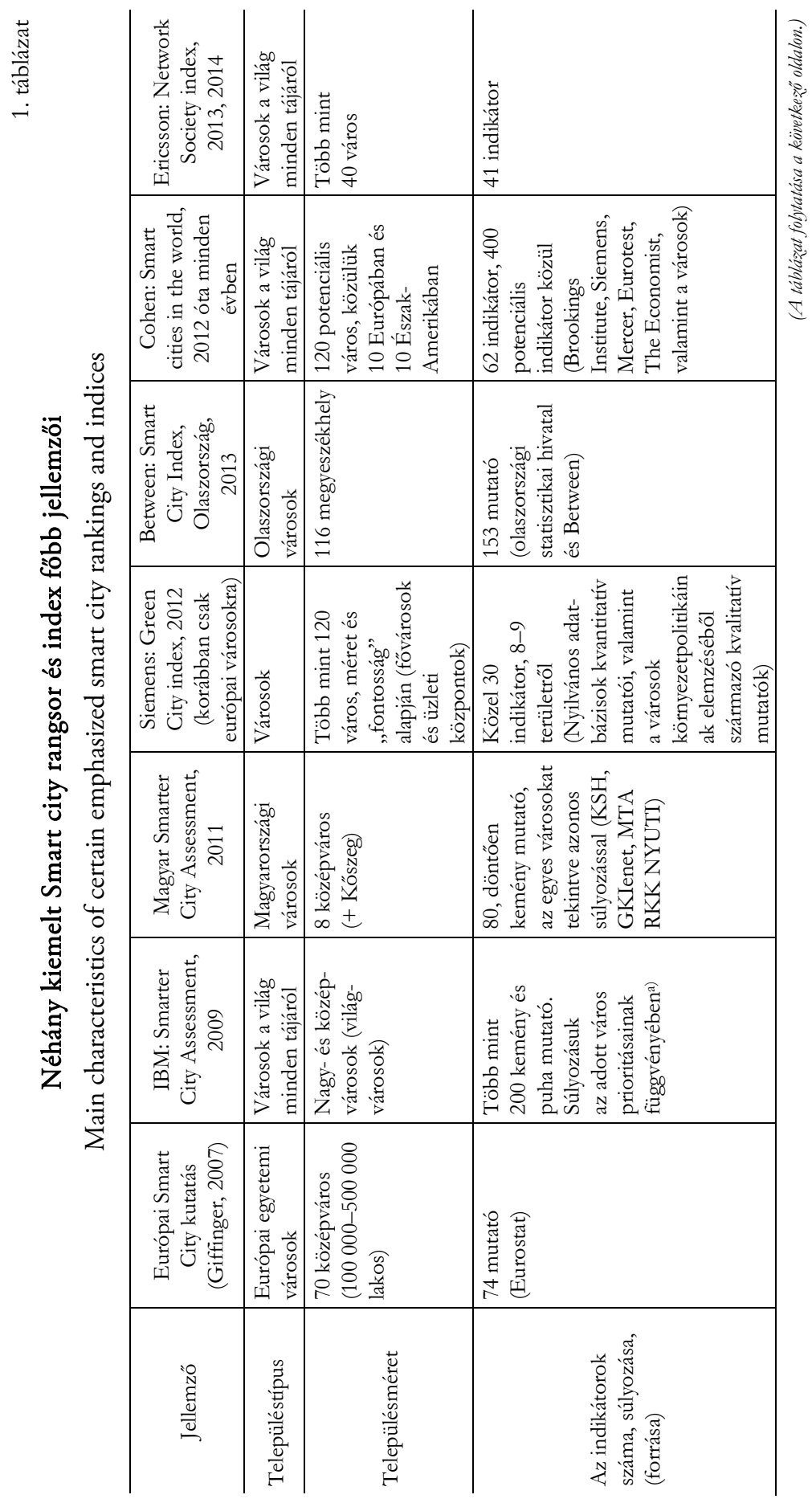

Területi Statisztika, 2019, 59(5): 555-574; DOI: 10.15196/TS590505 


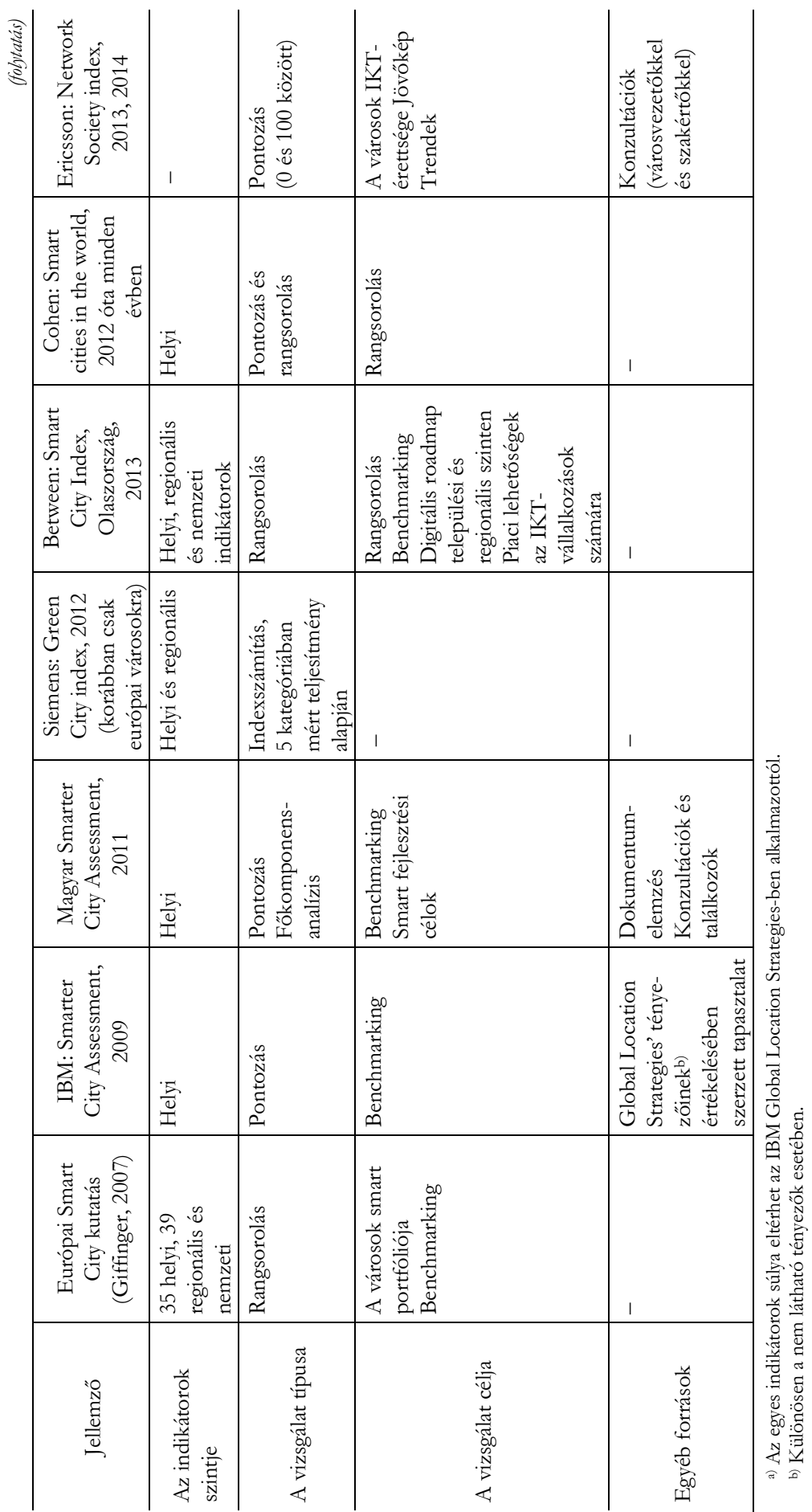

Területi Statisztika, 2019, 59(5): 555-574; DOI: 10.15196/TS590505 
Ennek ellenére a megvizsgált városrangsorok és indexek tanulmányozása során jelentős korlátok, valamint problémák merülnek fel az indikátorok használatában:

- Az adatgyújtés problémái. Az okos városok sikeres rangsorolásához jól definiált és települési szinten rendelkezésre álló indikátorok szükségesek. A legtöbb esetben a települési szintú indikátorok hiányoznak vagy nem frissülnek évente. A regionális vagy nemzeti szintú indikátorok használata öszszemossa az egyes települések közötti különbségeket. A legtöbb települési szintû adatot megfelelő érdekeltség hiányában nem gyűjtik vagy nem dolgozzák fel. Nagy mennyiségű adatforrást magánvállalkozások birtokolnak, így azok nem használhatóak fel kutatási vagy elemzési célokra. Az okos városok sikeres elemzéséhez nem pusztán „big data”, hanem „megfelelő adathalmaz" szükséges.

- Az adatok súlyozása és az indikátorok aggregálása jelentős mértékben befolyásolja a végső eredményeket.

- Átláthatósági problémák. Az adatok gyújtésének és feldolgozásának módszertana legtöbbször nem átlátható, nem nyilvános, annak ellenére sem, hogy az alkalmazott módszertan és a kiválasztott indikátorok jelentősen befolyásolják az eredményt.

- Az egyes indikátorok között, valamint az elemzés során használt egyes alrendszerek között a korreláció sok esetben igen szoros.

- Összehasonlíthatósági problémák. Az indikátorok tartalma és az adatfeldolgozás nem teljesen átlátható és heterogén, ezért az egyes rangsorok összehasonlíthatósága nagy akadályokba ütközik. Az okos városokról sok értékelést általában évente megismételnek (például Okos városok a világban [Smart cities in the world] rangsor Boyd Cohentől), de még ezeket sem lehet egymással összehasonlítani, mivel a felhasznált indikátorok és az elemzés módszertana évről évre változik.

- A dinamikus elemzés hiánya. Az indexek egy település okosságát, élhetőségét statikusan, egy meghatározott időpontban mutatják be. Így kevés információt nyerhetünk arról, hogyan fejlődik a város, milyen változások következnek be a település életében, vagy az hogyan reagál bizonyos helyzetekre és kritikus eseményekre. Annak ellenére, hogy pontosan ez utóbbi, vagyis a gyors reagálási idő és a változásokhoz való folyamatos alkalmazkodás lenne az okosság lényege. Egy város nem vizsgálható a környezetétől függetlenül, hiszen múködése befolyásolja a szomszédos települések életét, továbbá a környező települések dinamikus kölcsönhatással vannak egymásra és a városra is. Tehát a dinamikus megközelítés sokkal pontosabban ragadja meg az okosság belső tartalmát (Giovannella 2013).

- Az egyéni szempontok hiánya. A városokban emberek élnek, akiknek végső célja a város erőforrásainak hasznosítása olyan optimális módon, mellyel magasabb életminőséget érhetnek el. Megvannak a saját motivációik, elvárá- 
saik, szükségleteik és életstílusuk. Ha csak olyan indikátorokat, indexeket használunk a városok értékelése során, melyek egy adott időpontban mérnek a várossal kapcsolatos valamilyen információt (jövedelmet, iskolázottságot, szén-dioxid-kibocsátást stb.), és nem alkalmazunk más módszereket, akkor a vizsgálat nélkülözni fogja az egyéni szempontokat. Ezért egyre több kutatás, tanulmány elemzi az egyéni dimenziókat is, és a mutatószámok használata mellett, azokat kiegészítve olyan új módszereket alkalmaz, melyek építenek az egyének városra, területiségre vonatkozó saját tapasztalataira. Ilyen kutatások közé tartoznak például - a közösségi média felületein megjelenő bejegyzések mennyisége és minősége alapján - egy város érzelmi állapotának feltérképezése. Szövegelemző szoftverek segítségével ki tudják szúrni a városban élő, illetve a várost említő emberek érzelmi állapotát. Ezeket a vizsgálatokat dinamikus módon is el lehet végezni, így folyamatosan követhető egy város állapotának változása, akár bizonyos intézkedések után a változások is észlelhetőek.

Cohen (2015) szerint az okos városok legmagasabb szintje, az okos városok új generációja az, melyben az okos városok - a városlakókkal együttmúködve - formálódnak, múködnek. A város lakói aktívan részt vesznek a fejlesztési tevékenységekben, és minden közösséget érintő kérdésben, a megfizethető lakhatástól egészen az esélyegyenlőségig. A városi polgárok javaslataikkal, véleményükkel alakítják és formálják a város életét. Ezen a magasabb szinten tehát az okos városok központi eleme már nem pusztán a technológia, hanem a városban éló polgár. A városok nem egyszerúen a gazdaság motorjai többé, hanem olyan rendszerek, melyek célja az emberi jóllét növelése (Montgomery 2013). Azok a lakosok, akik kifejezhetik igényeiket, álmaikat a városukkal kapcsolatban, akik úgy érzik, hogy véleményüket meghallgatják, beleszólásuk lehet az épületek, a környezet, az utak, a zöldterületek kialakításába, azok elkötelezett és boldog polgárai lesznek a településnek.

Az utóbbi években több boldogságfelmérés, boldogság- és jóllétindex jött létre. Ezek mögött többféle magyarázat húzódik meg. Egyrészt a bruttó hazai termék (gross domestic product - GDP) mint a társadalmi fejlődés mérôszámának hiányosságai (Sen 1999, 2013, Clark 2005), valamint az alternatív és a zöld közgazdaságtan felől érkező kritikák (Jackson 2011, Austin 2016) felerősítették azokat a véleményeket, hogy más módon kellene mérni a gazdasági, társadalmi fejlődést. A boldogságfelmérések egy része nemzetek boldogságát vizsgálja, mint az ENSZ 2012 óta (Sachs et al. 2012) minden évben elkészített boldogságvizsgálata (World Happiness Report), mely megpróbálja számszerúsíteni a boldogságot globális szinten, a „bruttó nemzeti boldogság" indexének használatával. A Gazdasági Együttmúködési és Fejlesztési Szervezet (Organisation for Economic Co-operation and Development - OECD) pedig elkészítette a saját ajánlását a szubjektívjóllét-vizsgálatokra vonatkozóan (OECD 2013). Az OECD jóllétet vizsgáló mérési keretrendszere épít a társadalmak fejlődését és a jólétet vizsgáló nemzeti, nemzetközi kutatásokra

Területi Statisztika, 2019, 59(5): 555-574; DOI: 10.15196/TS590505 
(Kahneman-Krueger 2006, Diener 2006, Huppert et al. 2009), valamint Stiglitz és szerzőtársai jelentésére (2009), továbbá az OECD Statisztika és Statisztikai Szakpolitika Bizottságában helyet foglaló nemzeti statisztikai hivatalok inputjára.

Az OECD vizsgálatának legfontosabb jellemzői a következők:

- Az embereket (egyéneket és háztartásokat) helyezi az értékelés középpontjába.

- Az eredményekre fókuszál, tehát az élet azon aspektusaira, melyek közvetlenül érintik az embereket, nem az inputokra és az outputokra. Például az oktatási dimenzióban a mérés a megszerzett készségekre és kompetenciákra koncentrál, nem arra, hogy mennyi pénzt költöttek el az iskolákra, vagy hány tanárt képeztek.

- Egyaránt tartalmaz objektív (harmadik fél által begyújtött) adatokat és szubjektív elemeket (a válaszadók által kifejezett érzelmeket és állapotokat).

- Figyelembe veszi a lakosság egyes szegmenseinek, csoportjainak különbözőségét, különösen életkor, nemek, iskolázottság és jövedelem szempontjából (OECD 2015).

Ezzel párhuzamosan megjelentek a települések, elsősorban városok boldogságát vizsgáló indexek is. Az Egyesült Államokban a Gallup-Healthways minden évben elkészíti a városok, az államok és a választási kerületek jóllétét vizsgáló jelentését, mely folyamatos kérdőíves vizsgálatokon nyugszik (Gallup-Healthways 2012). Az Európai Unió szintén készített egy 79 városra kiterjedő életminőséget vizsgáló felmérést (Európai Bizottság 2013), továbbá nemzeti szintű jóllétet vizsgáló kutatásokat is folytattak, például az Egyesült Királyságban (Randall 2012), Ausztráliában (Lancy-Gruen 2013), Németországban (Government report 2017) is, melyekben a jóllétet és az emberek lakóhelyét összekapcsolták egymással.

Az Egyesült Királyságban végzett vizsgálatban például a következő területeket elemezték (Randall 2012):

- Lakáskörülményekkel való elégedettség.

- Közszolgáltatások fontossága.

- Lakásállomány.

- Lakáspiac.

- A helyi környezettel, területtel való elégedettség.

- A természethez való hozzáférés.

- A helyi szolgáltatásokhoz való hozzáférés.

A felmérések egy része az objektív tényezők mellett egyre inkább vizsgálja a boldogság, a jóllét szubjektív tényezőit is. Ezért a települések polgárai értékelik az egészségügyi állapotukat, a jólétüket, az elégedettségüket és a boldogságukat. Azok a városok, melyek kiemelkednek az objektív mutatók alapján, nem feltétlenül egyeznek meg azokkal, ahol az emberek a legelégedettebbek az életükkel (Ballas 2013). Az egyéni boldogság nagyban függhet az adott személy lakóhelyétől, környezetétől, azok állapotától, a helyi gazdasági környezettől, kulturális és szórakozási

Területi Statisztika, 2019, 59(5): 555-574; DOI: 10.15196/TS590505 
lehetőségektől, az épített és a természeti környezettől, a lakóhelyhez való kötődéstől, továbbá felveti azt is, hogy a boldogságvizsgálatokba szükséges beemelni a földrajzi és a területi aspektusokat is. Nemcsak a hatékonyság fontos, hanem az életminőség is. Önmagában a hatékonyság nem szükségszerủen teszi az embereket boldogabbá, és az okosváros-kutatásokból, valamint az okos városok irodalmából az emberek víziója, elvárásai, a várossal kapcsolatos benyomásai, érzelmei, érzékelései - mint perspektíva - szinte teljesen hiányoznak, ezért szükség van arra, hogy a mérés folyamatába bevonjuk a városban élőket is (Patel 2017, McKenna 2019).

Az objektív indikátorokat tartalmazó boldogságindexek, valamint a szubjektív elemeket beemelő, elsősorban önértékelésen alapuló felmérések mellett, a boldogság mint fogalom, vagy nehezen megragadható koncepció miatt számtalan olyan kezdeményezés született, mely nem a szokásos kérdőíven, hanem új, innovatív módon mérte azt, hogy mi teszi a város lakóit boldoggá. E módszerek építenek az új technológiák adta lehetőségekre is, hiszen soha nem látott mennyiségben keletkeznek valós idejú adatok, gyakorlatilag a települések életének minden szegmensét lefedve, a közlekedési rendszerektől az erőforrások felhasználásán át egészen a társadalmi kapcsolatokig. Ezek az adatok települési vagy településen belüli szinteken is rendelkezésre állnak, még akkor is új lehetőséget teremtve a területi kutatások számára, ha ezen adathalmazok elemzése során jelentős problémák merülnek fel (adattisztítás, az adatot létrehozók korlátozott száma, vagy speciális jellemzói miatt a reprezentativitás hiánya).

A szubjektív boldogság, elégedettség mérésére korábban használt módszerek elsősorban önbevallásos felméréseken alapultak (például napi tevékenységek, boldogság naplózása), jelentős mértékben függtek az egyes személyek önreflexiós képességétől, emlékezőképességétől, ezért egyrészt drágák voltak, másrészt sokszor nem eléggé megbízhatóak. Ezért olyan, új mérési módszerek jelentek meg, melyek az önbevallásos módszerek hiányosságait igyekeznek kiküszöbölni. Ide tartoznak például a közösségi médiafelületeket (twitter, flickr, facebook) vizsgáló kutatások.

A közösségi hálózatok, blogok, fórumok óriás potenciális információs bázist jelentenek a boldogságkutatások részére is. Az egyik legismertebb módszert Dodds és Dandorth (2009) dolgozta ki. A szerzőpáros épített Bradley és Lang (1999) tanulmánya alapján az angol szavak érzelmi normáinak (affective norms for English words - ANEW) módszerére, melynek során a résztvevők 1 és 9 közötti skálán több mint ezer szót értékeltek, 3 fő szempont alapján: jó-rossz (pszichológiai vegyérték, azaz a szóhoz társított érzelmi érték), aktív-passzív (izgalmi szint [arousal]), erős-gyenge (dominancia). Dodds és Dandorth (2009) csak a pszichológiai vegyértékre koncentráltak, mely szerint a szavakat az olvasóban kiváltott átlagos boldogság szintje szerint osztályozták. Egy teljes szöveg elemzésekor figyelembe vették az egyes ANEW-szavak pontszámát és gyakoriságát, ezek alapján számolták ki az adott szöveg végső pontszámát. Ezzel a módszerrel lehetőség nyílt arra, hogy

Területi Statisztika, 2019, 59(5): 555-574; DOI: 10.15196/TS590505 
olyan twitter-posztok szövegét elemezzék boldogság szempontjából, amelyekben geocímkézett tweetek elérhetőek voltak.

Mitchell és szerzőtársai (2013) az Egyesült Államok államaiban és városaiban vizsgálták a boldogságot, és a szövegelemzés mellett a népszámlálási adatokkal is összevetették eredményeiket. Úgy találták, hogy az Egyesült Államok államaiban ilyen módon mért boldogság szoros korrelációt mutatott az egyes államok gazdagságával. Ugyanakkor Easterlin (1974) paradoxonának megfelelően, hosszabb időtávot áttekintve, a GDP növekedésével a boldogság szintje nem növekedett, sőt csökkent. A boldogság erős negatív korrelációt mutatott az elhízással. Kramer (2010) facebook-státusfrissítések segítségével értékelte egy ország érzelmi egészségét. A státusfrissítések szövegének negatív vagy pozitív tartalmát, valamint gyakoriságát - Mithell és szerzőtársai (2013) munkájához hasonlóan - elemezte.

Quercia és szerzőtársai (2012) szintén tweetek alapján vizsgálták egyes közösségek boldogságát, és úgy találták, hogy a twitter új lehetőségeket kínál az emberek fizikai közösségeinek jellemzésére. A Londonban élők tweetjeit összevetették a nemzeti cenzusból származó társadalmi-gazdasági jólléti mutatókat tartalmazó deprivációs indexszel, és megállapították, hogy az online közösségi „,beszélgetések” szoros összefüggést mutatnak az adott közösség objektív fizikai valóságával.

\section{Összegzés}

Az okosváros-koncepció az elmúlt években egyre nagyobb figyelmet kapott a városok fejlődésével, versenyképességével foglalkozó kutatók, várostervezéssel, -menedzsmenttel foglalkozó szakemberek, IKT-vállalatok vezetői, valamint a média szereplői körében. Ennek ellenére sem alakult ki az okos városok egységes, mindenki által elfogadott definíciója.

Az okos városok középpontjában sokáig a technológia, az IKT állt. Napjainkra azonban tartalmuk jelentôsen módosult, és a fogalom átalakulásával, demokratizálódásával olyan városok, települések (akár kis falvak) számára is elérhető az okossá válás, melyek esetleg csak szúkös költségvetéssel, erőforrásokkal gazdálkodnak, hiszen minden település célja az ott lakó polgárok jóllétének növelése. Az okosság ebben az értelemben tehát nem jelent mást, mint az erőforrások, módszerek és technológiák minden érdekhordozó számára hasznos módon való alkalmazását, melynek végső célja egy sokkal méltányosabb és befogadóbb okos település létrehozása (Wardell Ghirarduzzi 2017). Szem előtt kell tartani, hogy a városok nem pusztán épületek vagy struktúrák, hanem azokat emberek alkotják (Glaeser 2012).

A boldogság és a szubjektív jóllét földrajzi, területi tárgyú vizsgálata egyelőre hiányzik, a témát mind ez ideig elsősorban pszichológiai, szociológiai és közgazdaságtani megközelítésből elemezték. A jövő kutatási feladatai közé tartozik a boldogság földrajzi szempontú feltárása annak érdekében, hogy megérthessük és megmagyarázhassuk, miért van jelentős különbség az egyes településeken élő emberek bol-

Területi Statisztika, 2019, 59(5): 555-574; DOI: 10.15196/TS590505 
dogsága között. Meg kell keresnünk azokat a térbeli jellemzőket, amelyek jelentősen hozzájárulhatnak a településeken élők jóllétének növeléséhez. Választ kell adni azokra a kérdésekre, hogy hogyan választhatók el egymástól az egyéni boldogságot meghatározó és a város által a boldogsághoz hozzáadott tényezők, valamint arra is, hogy hogyan kapcsolódik egymáshoz a személyes jóllét és a várossal való elégedettség. Nagyobb figyelmet kell fordítani a boldogság mérésének pontosítására, különösen a boldogság érzelmileg színezett, külső hatásokra fogékony elemeinek mérésére. A korábban alkalmazott objektív mutatók, valamint a kérdőíves, önbevalláson alapuló mérési módszerek mellett elengedhetetlen az emberek érzékeléseinek, benyomásainak vizsgálata is.

A városok boldogságának kutatásához interdiszciplináris szemlélet szükséges, mert csak ilyen módon érthetjük meg pontosan, hogy mi tesz egy várost boldoggá, élhetóvé. Ezek kiindulópontjai lehetnek a korábban már sikeresen kialakított városi és regionális életminőségi indikátorok, melyeket a jóllét és a boldogság szubjektív elemei egészíthetnek ki. Az ilyen kutatások, vizsgálatok lebonyolításához ugyanakkor különböző tudományágak (szociológia, regionális és várostervezés, pszichológia, közgazdaságtan, földrajz) széles körű összefogására van szükség (Ballas 2013, S47. old.).

\section{IRODALOM}

ARISZTOTELÉSZ (1997): Nikomakhoszi Etika. Európa, Budapest.

AsLAm, A.-CORRADO, L. (2007): No man is an island: The inter-personal determinants of regional wellbeing in Europe, Cambridge Working Papers in Economics No. 717.

Austin, A (2016): On well-being and public policy: Are we capable of questioning the hegemony of happiness? Social Indicators Research 127 (1): 123-138. https://doi.org/10.1007/s11205-015-0955-0

BALLAS, D. (2013): What makes a „happy city”? Cities 32: S39-S50. https://doi.org/10.1016/j.cities.2013.04.009

Ballas, D.-Tranmer, M. (2012): Happy people or happy places? A multilevel modeling approach to the analysis of happiness and well-being International Regional Science Review 35 (1): 70-102. https://doi.org/10.1177/0160017611403737

BARSI, B. (2018): Beyond indicators, new methods in smart city assessment Smart Cities and Regional Development 2 (1): 87-99.

BARSI, B.- CsizMADIA, Z. (2001): Egy nagyváros helyzete az információs társadalomban Tér és Társadalom 15 (2): 147-172. https://doi.org/10.17649/tet.15.2.807

BARSI, B. (2002): Egy kisváros helyzete az információs korban Tér és Társadalom 16 (3): 85-102. https://doi.org/10.17649/TET.16.3.1981

BELUSZKY, P.-GYŐRI, R. (2006): A magyar városhálózat funkcionális versenyképessége. In: HorvÁTH, Gy. (szerk.): Régiók és települések, versenyképessége pp. 236-294., MTA RKK, Pécs.

Területi Statisztika, 2019, 59(5): 555-574; DOI: 10.15196/TS590505 
BeluszKy, P. (1999): Magyarország településföldrajza Dialóg-Campus Kiadó, Budapest-Pécs.

BIN BISHR, A. (2018): Happy cities in a smart world In: Global happiness policy report pp. 158-200., Global Happiness Council.

BRADley, M. M.-Lang, P. J. (1999): Affective norms for English words (ANEW): Instruction manual and affective ratings Technical Report C-1 The Center for Research in Psychophysiology, University of Florida.

Brereton, F.-Clinch, J. P.-Ferreira, S. (2008): Happiness, geography and the environment Ecological Economics 65 (2): 386-396. https://doi.org/10.1016/j.ecolecon.2007.07.008

Caragliu, A.-Del Bo, C.-Nijkamp, P. (2011): Smart cities in Europe Journal of Urban Technology 18 (2): 65-82. https://doi.org/10.1080/10630732.2011.601117

Clark, A. E. (2003): Unemployment as a Social Norm: Psychological Evidence From Panel Data Journal of Labor Economics 21 (2): 323-351. https://doi.org/10.1086/345560

Clark, A.-Diener, E.-Georgellis, Y.-Lucas, R. E. (2008): Lags and leads in life satisfaction: A test of the baseline hypothesis Economic Journal 118 (529): F222F243. https://doi.org/10.1111/j.1468-0297.2008.02150.x

CLARK, D. A. (2005): Sen's capability approach and the many spaces of human well-being Journal of Development Studies 41 (8): 1339-1368. https://doi.org/10.1080/00220380500186853

Cummins, R. A.-Eckersley, R.-Pallant, J.-Van Vugt, J.-Misajon, R. (2003): Developing a national index of subjective wellbeing: The Australian Unity Wellbeing Index Social Indicators Research 64 (2): 159-190.

CSAPÓ, T. (2002): A magyar megyei jogú városok regionális funkciói Területi Statisztikea 42 (3): 228-252.

Csikszentminalyi, M. (1992): The Flow: The Psychology of Happiness Rider, London.

Dameri, R. P. (2017): Smart City Definition, Goals and Performance In: Smart City Implementation. Progress in IS Springer, Cham.

Davern, M. T.-Chen, X. (2010): Piloting the geographic information system (GIS) methodology as an analytic tool for subjective wellbeing research Applied Research in Quality of Life 5 (2): 105-119. https://doi.org/10.1007/s11482-010-9095-5

DiENER, E. (2000): Subjective well-being: the science of happiness and a proposal for a national index American Psychologist 55 (1): 34-43. https://doi.org/10.1037//0003-066x.55.1.34

DIENER, E. (2006): Guidelines for national indicators of subjective well-being and ill-being Journal of Happiness Studies 7 (4): 397-404. https://doi.org/10.1007/s10902-006-9000-y

Diener, E.-Suh, E. M.-LuCAS, R. E.-SMith, H. L. (1999): Subjective well-being: Three decades of progress Psychological Bulletin 125 (2): 276-302. https://doi.org/10.1037/0033-2909.125.2.276 
DodDs, P. S.-DANFORTH, C. M. (2010): Measuring the happiness of large-scale written expression: Songs, blogs, and presidents Journal of Happiness Studies 11 (4): $441-456$.

1 citations from patents https://doi.org/10.1007/s10902-009-9150-9

DÖvÉNYI, Z. (2003): Városállomány, urbanizáció, városok. In: PERCZEL, GY. (szerk.): Magyarország társadalmi-gazdasági földrajz̨a pp. 536-551., ELTE Eötvös Kiadó, Budapest.

EASTERLIN, R. (1974): Does economic growth improve the human lot? Some empirical evidence. In: DAVIS, P. A.-REDER, M. W. (eds.): Nation and households in economic growth: Essays in honor of moses abromowitz pp. 89-125., Academic Press, New York.

EID, M.-LARSEN, R. J. (2008): The Science of Subjective Well-Being. The Guilford Press, New York.

EURóPAi BizotTSÁG (2013): Quality of life in cities Publications Office of the European Union, Luxembourg.

Giffinger, R.-FERTNer, C.-Kramar, H.-KAlaseK, R. (2007): Smart cities. Ranking of European medium sized cities Centre of Regional Science, Vienna UT, Vienna.

GIFFINGER, R.-GUDRUN, H. (2010): Smart cities ranking: an effective instrument for positioning of the cities? ACE: Architecture, City and Environment 2010 (12): 7-25. https://doi.org/10.5821/ace.v4i12.2483

Giovannella, C. (2013): Territorial Smartness and Emergent Behaviors In: 2nd International Conference on Systems and Computer Science pp. 170-176. https://doi.org/10.1109/icconscs.2013.6632042

GLAESER, E. (2012): Triumph of the city; How urban spaces make us human Pan, London.

GOVERnMENT REPORT (2017): Government Report on Wellbeing in Germany Federal Press Office, Berlin.

Harrison, C.-Donnelly, I. A. (2011): A Theory of Smart Cities In: Proceedings of the 55th Annual Meeting of the ISSS Full Paper, pp. 1-15., International Society for the Systems Sciences.

Hills, P.-Argyle, M. (1998): Positive moods derived from leisure and their relationship to happiness and personality Personality and Individual Differences 25 (3): 523-535.

Jackson, T. (2011): Prosperity without Growth: Economics for a Finite Planet Abingdon, Routledge.

JaCoBs, J. (1961): The Death and Life of Great American Cities Random House, New York.

Kahneman, D.-Krueger, A. B. (2006): Developments in the Measurement of Subjective Well-Being Journal of Economic Perspectives 20 (1): 19-20.

KNight, J.-GunAtiLAKA, R. (2010): The rural-urban divide in China: Income but not happiness? Journal of Development Studies 46 (3): 506-534. https://doi.org/10.1080/00220380903012763

Kőszegfalvi, Gy.-TóTH J. (1998): Általános településföldrajz In: TóTH, J.-Vuics, T. (szerk.): Altalános társadalomföldrajz. I. Dialóg-Campus, Budapest-Pécs.

Kramer, A. D. I. (2010): An unobtrusive behavioral model of "Gross National Happiness" In: Proceedings of the ACM Conference on Human Factors in Computing Systems (CHI 2010), pp. 287-290., ACM Press, New York.

LANCY, A.-GRUEN, N. (2013): Constructing the herald/age - Lateral economics index of Australia's wellbeing Australian Economic Review 46 (1): 92-102.

Területi Statisztika, 2019, 59(5): 555-574; DOI: 10.15196/TS590505 
https://doi.org/10.1111/j.1467-8462.2013.12000.x

LANE, R. (2000): The loss of happiness in market economies CT: Yale University Press, New Haven.

LAYARD, R. (2005): Happiness: Lessons from a new Science Penguin Press, New York.

LENGYEL, I.-RECHNiTZER, J. (2000): A városok versenyképességéről In: HoRvÁTH, GY.-RECHNITZER, J. (szerk.): Magyarország területi szerkezzete és folyamatai az ezredfordulón pp. 130-152., MTA RKK, Pécs.

LEYDEN, K. M. (2003): Social capital and the built environment: The importance of walkable neighborhoods American Journal of Public Health 93 (9): 1546-1551.

Leyden, K. M.-Goldberg, A.-MichelBACH, P. (2011): Understanding the pursuit of happiness in ten major cities Urban Affairs Review 47 (6): 861-888. https://doi.org/10.1177/1078087411403120

LuDASsy, M. (1991): Az angolszász liberalizmus klasszikusai I-II. Atlantisz, Budapest.

LuTTMER, E. F. P. (2005): Neighbors as negatives: Relative earnings and wellbeing Quarterly Journal of Economics 120 (3): 963-1002. https://doi.org/10.1162/003355305774268255

Millward, H.-SPINNEY, J. (2013): Urban-rural variation in satisfaction with life: Demographic, health, and geographic predictors in Halifax Canada Applied Research in Quality of Life 8 (3): 279-297. https://doi.org/10.1007/s11482-012-9194-6

Mitchell, L.-FranK, M. R.-HARris, K. D.-DodDs, P. S.-DANFORTH, C. M. (2013): The geography of happiness: Connecting twitter sentiment and expression demographics and objective characteristics of place PLOS ONE 8 (5): e64417. https://doi.org/10.1371/journal.pone.0064417

Montgomery, C. (2013): Happy city: Transforming our lives through urban design Random House, New York.

MorA, L.-BOLICI, R.-DEAKIN, M. (2017): The first two decades of smart-city research: A bibliometric analysis Journal of Urban Technology 24 (1): 3-27. https://doi.org/10.1080/10630732.2017.1285123

Neirotti, P.-De Marco, A.-Cagliano, A. C.-Mangano, G.-Scorrano, F. (2014): Current trends in smart city initiatives: Some stylised facts cities 38: 25-36. https://doi.org/10.1016/j.cities.2013.12.010

OECD [Organsation for Economc Co-operation and Develeopment] (2013): OECD guidelines on measuring subjective well-being OECD Publishing, Paris. https://doi.org/10.1787/9789264191655-en

Oldenburg, R. (1989) The great good place. Da Capo Press, Boston.

PARK, R. E.-Burgess, E.-MCKENZIE, R. D. (1925): The city: Suggestions for the study of human nature in the urban environment University of Chicago Press, Chicago.

PORTEOUs, J. D. (1977): Environmental and behavior: planning and everyday urban life Reading, Massachusetts: Addison-Wesley.

PutnAm, R. (2000): Bowling alone: The collapse and revival of American community Simon \& Schuster, New York.

RANDALL, C. (2012): Measuring national well-being - Where we live - 2012. Technical Report July UK Office for National Statistics.

Területi Statisztika, 2019, 59(5): 555-574; DOI: 10.15196/TS590505 
RatzlafF, C.-Matsumoto, D.-Kuznetzova, N.-Raroque, J.-Ray, R. (2000): Culture and subjective well-Being Massachusetts Institute of Technology, Boston.

RECHNITZER, J. (2002): A városhálózat az átmenetben, a kilencvenes évek változási irányai Tér és Társadalom 16 (3): 165-183.

ReChnitzer, J.-Grosz, A.-CsizmadiA, Z. (2003): A magyar városhálózat tagozódása az infokommunikációs infrastruktúra alapján az ezredfordulón Tér és Társadalom 17 (3): 145-163. https://doi.org/10.17649/TET.17.3.905

SACHS, J. D.-LAYARD, R.-HELLIWELL, J. F. (2012): World happiness report. Technical report Columbia University/Canadian Institute for Advanced Research/London School of Economics.

SEN, A. (1999): Development as freedom Oxford University Press, Oxford.

Sen, A. (2013): The ends and means of sustainability Journal of Human Development and Capabilities 14 (1): 6-20. https://doi.org/10.1080/19452829.2012.747492

SEPE, M. (2017): The Role Of Public Space To Achieve Urban Happiness International Journal of Sustainable Development and Planning 12 (4): 724-733. https://doi.org/10.2495/sdp-v12-n4-724-733

SHIN, D. C.-Johnson, D. M. (1978): Avowed happiness as an overall assessment of the quality of life. Social Indicators Research 5 (1-4): 475-492.

SHucksmith, M.-CAMERON, S.-MERRIDEW, T.-PiCHLER, F. (2009): Urban-rural differences in quality of life across the European Union. Regional Studies 43 (10): 1275-1289.

https://doi.org/10.1080/00343400802378750

TÓTH, J. (1996): Településrendszer fejlődése In: PERCZEL, GY. (szerk.): Magyarország társadalmi-gazdasági földrajza pp. 539-586., Budapest, ELTE Eötvös Kiadó.

WHO (1998): The World Health Organization quality of life assessment (WHOQOL): development and general psychometric properties. Social Science and Medicine 46 (12): 1569-1585.

\section{INTERNETES HIVATKOZÁSOK}

BALLAS, D. (2007): Exploring geographies of happiness in Britain and the implications for public policy Department of Geography, University of Sheffield. http://www.uptap.net/wordpress/

COHEN, B. (2012): The top 10 smart cities on the Planet (2012).

http://www.fastcoexist.com/1679127/the-top-10-smart-cities-on-the-planet

COHEN, B. (2015): The 3 generations of smart cities - Inside the development of the technology driven city Fast Company.

https://www.fastcompany.com/3047795/the-3-generations-of-smart-cities

COHEN, B. (2017): A smart city is a happy city.

https://innovationorigins.com/smart-city-happy-city/

Gallup-HealthWays (2012): State of well-being 2011: City, state and congressional district wellbeing reports. Technical report Gallup Inc. http://www.wellbeingindex.com/files/2011CompositeReport.pdf (letöltve: 2018. július 23.)

Területi Statisztika, 2019, 59(5): 555-574; DOI: 10.15196/TS590505 
HUPPERT FA, SO TTC. (2009): What percentage of people in Europe are flourishing and what characterises them?; Well-Being Institute, University of Cambridge, mimeo prepared for the OECD/ISQOLS meeting on Measuring subjective well-being: an opportunity for NSOs; Florence. 23/24 July www.isqols2009.istitutodeglinnocenti.it/Content_en/Huppert.pdf (letöltve: 2018. október)

LADOS, M.-HORVÁTHNÉ BARSI, B. (2011): IBM „Smart cities” tanulmány. https://www-05.ibm.com/hu/download/IBM_SmarterCity_20110721.pdf

MCKenNA, P. H. (2019): Innovating metrics for smarter, responsive cities data Voluma 4. Issue 1. https://res.mdpi.com/data/data-04-00025/article_deploy/data04-00025-v2.pdf?filename $=\&$ attachment $=1$ (letöltve: 2019 . június)

OECD [Organsation for Economc Co-operation and Develeopment] (2015): How's life? Measuring well-being OECD Publishing, Paris. https://dx.doi.org/10.1787/how_life-2015-en.

PATEL, A. (2017): Wonder as an interruption. Conscious Cities https://www.ccities.org/wonder-as-an-interruption/ (letöltve: 2018. április)

Quercia, D. O.-SeaghdHA, D.-Crowcroft, J. (2012): Talk of the city: Our tweets, Our community happiness In: Proceedings of the Sixth International AAAI Conference on Weblogs and Social Media pp. 555-558. https://www.aaai.org/ocs/index.php/ICWSM/ICWSM12/paper/viewF ile/4611/5056 (letöltve: 2018. július 30.)

Stiglitz, J. E.-SEN, A.-Fitoussi, J. P. (2009): Report by the Commission on the Measurement of Economic Performance and Social Progress www.insee.fr/en/information/2662494.

WARDELL GHIRARDUZZI, M. (2017): Equity in smart cities: The mythof neutrality http://meetingoftheminds.org/equity-smart-cities-myth-neutrality-20071 (letöltve: 2018. július 29.) 